\title{
The Responsibility to Protect and the Use of Force: Building Legality?
}

\author{
Jutta Brunnée and Stephen J. Toope
}

Version Post-print/accepted manuscript

Citation Brunnée, Jutta and Toope, Stephen J., The Responsibility to Protect and (published version) the Use of Force: Building Legality? (February 11, 2010). Global Responsibility to Protect, 2 no. 3 (June 1, 2010): 191-212

Publisher's Statement This is the peer reviewed version of Brunnée, Jutta and Toope, Stephen J., The Responsibility to Protect and the Use of Force: Building Legality? (February 11, 2010). Global Responsibility to Protect, 2 no. 3 (June 1, 2010): 191-212

This article can be found in its final form at https://doi.org/10.1163/187598410x500354

How to cite TSpace items

Always cite the published version, so the author(s) will receive recognition through services that track citation counts, e.g. Scopus. If you need to cite the page number of the author manuscript from TSpace because you cannot access the published version, then cite the TSpace version in addition to the published version using the permanent URI (handle) found on the record page.

This article was made openly accessible by $U$ of $T$ Faculty. Please tell us how this access benefits you. Your story matters. 


\title{
The Responsibility to Protect and the Use of Force: Building Legality?
}

\author{
(C) Jutta Brunnée and Stephen J. Toope*
}

[A final version of this paper will appear in (2010) 2/3 Global Responsibility to Protect.]

\section{Introduction}

In July 2009, the United Nations General Assembly held two and a half days of plenary debate on the report that Secretary General Ban-Ki Moon had submitted on 'Implementing the Responsibility to Protect.' 1 The interventions of 94 speakers, representing a remarkable 180 member states and groups of states, as well as two observers, ${ }^{2}$ suggest that support for the responsibility to protect is growing around the world. Only a small number of states continue directly to challenge the emerging norm; most are looking to refine it, especially as it relates to the use of force.

Our focus in this article is on this latter, most controversial, dimension of the responsibility to protect. As outlined in the 2005 World Summit Outcome document [Summit Outcome], the responsibility to protect encompasses the possibility of collective military action through the Security Council. Such action would be taken on a 'case by case basis,' and only as a last resort, 'should peaceful means be inadequate and national authorities manifestly fail to protect their populations' from 'genocide, war crimes, ethnic cleansing and crimes against humanity. ${ }^{3}$ However, many states remain concerned about the parameters for military action, asking who would determine whether a situation involves one of the specified international crimes; calling for criteria to guide decisions on whether and when the use of force is appropriate; and suggesting that permanent members of the Security Council not use their veto power in cases involving the responsibility to protect.

\footnotetext{
* Metcalf Chair in Environmental Law, Faculty of Law, University of Toronto; and President and ViceChancellor, University of British Columbia, respectively. This paper draws upon Jutta Brunnée, 'International Law and Collective Concerns: Reflections on the Responsibility to Protect', in Tafsir Malick Ndiaye and Rüdiger Wolfrum, eds., Law of the Sea, Environmental Law and Settlement of Disputes (Leiden: Martinus Nijhoff, 2007), pp. 48-51; and Jutta Brunnée and Stephen J. Toope, Legitimacy and Legality in International Law: An Interactional Account (Cambridge: Cambridge University Press, forthcoming 2010).

${ }^{1}$ Implementing the Responsibility to Protect, Report by the Secretary-General, UN Doc. A/63/677, 12 January 2009; http://daccessdds.un.org/doc/UNDOC/GEN/N09/206/10/PDF/N0920610.pdf?OpenElement.

${ }^{2}$ See Global Centre for the Responsibility to Protect, Implementing the Responsibility to Protect- The 2009 General Assembly Debate: An Assessment, August 2009, p. 1; at http://www.responsibilitytoprotect.org/index.php/component/content/article/35-r2pcs-topics/2522-reportby-the-global-centre-for-r2p-the-2009-general-assembly-debate-an-assessment-.

${ }^{3}$ UN General Assembly, 2005 World Summit Outcome, UN Doc. A/RES/60/1 (24 October 2005), para.138-139; at www.un.org/summit2005/documents.html.
} 
The relatively rapid rise of the responsibility to protect provides us with a unique opportunity to consider the impact of a decade or so of determined norm entrepreneurship. Most observers today conclude that the responsibility to protect has not yet become a binding norm of international law. ${ }^{4}$ We share this assessment, but we believe it is important to take a closer look at what it would take for the responsibility to protect to become legally binding, and what factors are holding back or promoting this development. In our view, a standard assessment of whether or not the norm has become binding as customary or treaty law is not sufficiently nuanced to reveal the salient dynamics.

In this article, we offer a more finely grained perspective on how international law is created and maintained. We draw on what we call an 'interactional' account of international law, which focuses on three inter-locking elements. ${ }^{5}$ First, legal norms are social norms and as such they are connected to social practice - they must be grounded in shared understandings. Second, what distinguishes law from other types of social ordering is not so much form or pedigree, as adherence to specific criteria of legality: generality, promulgation, non-retroactivity, clarity, non-contradiction, not asking the impossible, constancy, and congruence between rules and official action. When norm creation meets these criteria and, third, is matched with norm application that also satisfies the legality requirements, international law will have legitimacy and generate a sense of commitment among those to whom it is addressed.

We first highlight key steps in the norm building process so far, beginning with the 2001 report of the International Commission on Intervention and State Sovereignty (ICISS) and leading to the debate in the General Assembly in 2009. Next we offer a brief sketch of our theoretical framework, employing it to examine the trajectory of the responsibility to protect norm. We consider the evolution of shared normative understandings, especially concerning the protective use of force through the Security Council. We then assess the collective action aspects of the emerging norm against the requirements of legality. We conclude that the norm as it is currently articulated fares poorly on several of the abovementioned criteria, notably on generality, clarity, consistency, constancy, and congruence between norm and practice. The continuing debates about appropriate parameters for recourse to force can, we suggest, be read as debates about strengthening the legality of the responsibility to protect, and hence about whether to build it into a legal norm or not. By implication, they are also debates about the extent to which political decision-making in the Security Council should yield to considerations of legality.

\footnotetext{
${ }^{4}$ See e.g. Max W. Matthews, 'Tracking the Emergence of a New International Norm: The Responsibility to Protect and the Crisis in Darfur' B.C. Int'l Comp. L. Rev. 31: 137-152 (2008); Carsten Stahn, 'Responsibility to Protect: Political Rhetoric or Emerging Legal Norm?' American Journal of International Law 101: 99-120 (2007).

5 Jutta Brunnée and Stephen J. Toope, Legitimacy and Legality in International Law: An Interactional Account (Cambridge: Cambridge University Press, forthcoming 2010). (The book offers a novel account of how international legal obligation is created and maintained, drawing together the work of legal theorist, Lon Fuller, and insights of constructivist International Relations scholars).
} 


\section{The Norm Building Process}

The surprisingly rapid evolution of the concept of responsibility to protect over the last fifteen years or so was driven in large part by extraordinarily grave human rights crises in certain countries, as well as by the failure of the world community to intervene to prevent further atrocities from being perpetrated upon civilian populations. The Rwandan genocide encapsulates this failure, ${ }^{6}$ but it is not a unique case, as the horrors of Cambodia, Zaire/Congo, Liberia, Sierra Leone and, most recently, Darfur attest. These crises prompted the African Union to provide, in its Constitutive Act of 2000, for a right of the Union to intervene in a member state in the case of "grave circumstances, namely: war crimes, genocide and crimes against humanity. ${ }^{7}$ However, the immediate impetus for concerted global efforts to elaborate the concept of responsibility to protect was arguably provided by the NATO intervention in Kosovo in 1999. Kosovo raised again the fundamental questions whether or not a norm of humanitarian intervention existed and, if so, who could invoke it, only the Security Council or individual states? ${ }^{8}$ In justifying the intervention, most of the NATO states (with the exception of Belgium) side-stepped these thorny issues and refused to posit a general norm of humanitarian intervention. Instead, the NATO partners argued a 'moral duty' or a 'necessity' to act. ${ }^{9}$

Shortly after Kosovo, Canada, one of the participants in the NATO intervention, promoted the creation of an independent International Commission on Intervention and State Sovereignty. ${ }^{10}$ In its articulation of the responsibility to protect,,${ }^{11}$ the ICISS sought to transcend the intractable debates surrounding a 'right' to humanitarian intervention. ${ }^{12}$ The responsibility to protect was not about rights at all, but about duties. The primary duty holder was the sovereign state, which should offer security and protection to its own citizens. The report emphasized the overriding importance of a wide spectrum of proactive measures and assistance to local governments in discharging their responsibility

\footnotetext{
${ }^{6}$ See, e.g., Michael Barnett, Eyewitness to a Genocide: the United Nations and Rwanda (Ithaca, NY: Cornell University Press, 2002).

7 African Union, Constitutive Act (2000), Article 4 (h); at http://www.africaunion.org/root/au/AboutAu/Constitutive_Act_en.htm

${ }^{8}$ Independent International Commission on Kosovo, The Kosovo Report - Conflict, International Response, Lessons Learned (2000).

${ }^{9}$ See e.g. Javier Solana, Secretary-General of NATO, Press Statement, NATO Press Release (1999) 040, 23 March 1999, at www.nato.int/docu/pr/1999/p99-040e.htm. Or see Declaration by the [UK] Parliamentary Under Secretary of State, reprinted in British Yearbook of International Law 69: 593 (1998) (claiming that "in the exceptional circumstances of Kosovo it was considered that the use of force would be justified on the ground of overwhelming humanitarian necessity, without Security Council authorization”).

${ }^{10}$ International Commission on Intervention and State Sovereignty (ICISS), The Responsibility to Protect, December 2001; at www.dfait-maeci.gc.ca/iciss-ciise/report-en.asp.

${ }^{11}$ Of course, the idea of a responsibility to protect can be traced further back. See e.g. Olivier Corten and Pierre Klein, Droit d'ingérence ou obligation de réaction? Les possibilités d'action visant à assurer le respect des droits de la personne face au principe de non-intervention (Brussels: Bruylant, 1992); and Francis M. Deng, et al, Sovereignty as Responsibility: Conflict Management in Africa (Washington, D.C.: Brookings Institution Press, 1996).

${ }^{12}$ See e.g. J. L. Holzgrefe and Robert O. Keohane, eds., Humanitarian Intervention: Ethical, Legal and Political Dilemmas (Cambridge: Cambridge University Press, 2003).
} 
to protect, as well as the importance of non-military forms of pressure. ${ }^{13}$ But it also offered a set of carefully crafted threshold criteria for recourse to collective military action where there was 'serious and irreparable harm occurring to human beings, or imminently likely to occur.' The triggering events identified by ICISS were 'large scale loss of life ... with genocidal intent or not, which [was] the product either of deliberate state action, or state neglect, or inability to act, or a failed state situation,' or 'large scale ethnic cleansing. ${ }^{14}$ In cases where a state failed in its protective obligation, or where it was the perpetrator of massive human rights violations, collective military action could be authorized internationally to protect victims within a sovereign state. ${ }^{15}$ To guide decisions on military action, the ICISS outlined a 'just cause threshold,' a set of 'precautionary principles,' and criteria for 'right authority.' 16 While the Commission identified the Security Council as the most appropriate body for decisions on military intervention for human protection purposes, it warned that individual states might feel compelled to act in the face of inaction by the Council. ${ }^{17}$ To avoid Council paralysis, the ICISS report recommended that permanent members agree to a 'code of conduct' for the use of the veto in relation to actions needed to stop or avert a significant humanitarian crisis. $^{18}$

The ICISS report was released shortly after the attacks of 11 September 2001. The sensitivity of its recommendations was further increased by the intervention in Iraq, led by the United States and Britain without authorization by the Security Council. ${ }^{19}$ By November 2003, the worry over the 'lack of agreement amongst Member States on the proper role of the United Nations in providing collective security' prompted then UN Secretary General, Kofi Annan, to convene the High-level Panel on Threats, Challenges and Change. $^{20}$ The panel's report was published in December 2004. ${ }^{21}$ With respect to the use of force for the protection of people, the report drew extensively on the ICISS recommendations. The panel endorsed 'the emerging norm that there is a collective international responsibility to protect, exercisable by the Security Council authorizing military intervention as a last resort.' 22 The High-level Panel's invocation of triggering events for collective military action was similar to that of ICISS: 'genocide and other large scale killing, ethnic cleansing or serious violation of international humanitarian

\footnotetext{
${ }^{13}$ ICISS, The Responsibility to Protect, at 19-31.

${ }^{14}$ Ibid., at XII, and 32.

${ }^{15}$ ICISS envisaged that this authorization should be sought first through the Security Council, and in case of an inability or refusal to act, through a revitalization of the "Uniting for Peace" resolution of the General Assembly or through a reference to a regional organization. See ICISS, ibid., at XII-XIII, and 47-51.

${ }^{16}$ Ibid., at XII. For a detailed discussion, see Jutta Brunnée and Stephen J. Toope, 'Slouching Towards New Just Wars: International Law and the Use of Force after September 11', NILR LI: 363-392 (2004).

${ }^{17}$ Ibid., at XII and 47-55; XIII.

${ }^{18}$ Ibid., at XIII and 51.

${ }^{19}$ See Jutta Brunnée and Stephen J. Toope, 'The Use of Force: International Law After Iraq', International \& Comparative Law Quarterly 53: 785-806 (2004).

${ }^{20}$ In Larger Freedom: Towards development, security and human rights for all, Report by the SecretaryGeneral, UN Doc. A/59.2005, 21 March 2005, at para. 76; at www.un.org/largerfreedom/contents.htm.

${ }^{21}$ A more secure world: our shared responsibility, Report of the High-level Panel on Threats, Challenges and Change, UN Doc. A/59/565 (29 November 2004); at http://www.un.org/secureworld.

${ }^{22}$ Ibid., para. 203.
} 
law. ${ }^{23}$ In addition, the panel emphasized that guidelines on the use of force, whether to address external threats to states' security or grave humanitarian crises within states, could 'maximize the possibility of achieving Security Council consensus,' and 'minimize the possibility of individual Member States bypassing the Security Council. ${ }^{24}$ The criteria, which the panel suggested should be 'embodied in declaratory resolutions of the Security Council and the General Assembly,' were: seriousness of threat, proper purpose, last resort, proportional means, and balance of consequences. ${ }^{25}$

In his response to the High-level Panel report, the Secretary-General highlighted the question whether states have the right, or even obligation, to use force protectively to rescue citizens from genocide or comparable crimes against humanity. ${ }^{26}$ This move from a list of grave human rights violations to the concept of international crime as the trigger for action represented a crucial shift in emphasis. Another shift was equally important. Whereas both ICISS and the High-level Panel had left open the possibility of unilateral action where the Security Council could not act in the face of crisis, the SecretaryGeneral's response stressed that the task was 'not to find alternatives to the Security Council as a source of authority but to make it work better. ${ }^{27}$ To this end, the SecretaryGeneral endorsed ICISS' and the High-level Panel's calls for criteria for intervention, emphasizing that the formulation and application of such criteria was essential to achieve legitimacy amongst states and global public opinion for any Council action. ${ }^{28}$

The concept of the responsibility to protect found its way into the 2005 Summit Outcome document, with a number of further shifts in emphasis. The Summit Outcome stresses that the responsibility is first and foremost one of individual states to protect their populations. In addition, the link between the concept and international crimes was solidified, as states are only called upon to protect their populations from 'genocide, war crimes, ethnic cleansing and crimes against humanity. ${ }^{, 29}$ Responsibilities are posited also for 'the international community,' but these are to 'encourage and help States' to exercise their responsibility to protect their own people, and to 'use appropriate diplomatic, humanitarian and other peaceful means...to help protect populations. ${ }^{30}$ Finally, under Chapter VII of the UN Charter, collective action can be taken through the Security Council, on a 'case by case basis' and 'should peaceful means be inadequate and national authorities manifestly fail to protect their populations' from the listed

\footnotetext{
${ }^{23}$ Ibid.

${ }^{24}$ Ibid., para. 206.

${ }^{25}$ Ibid., paras. 207-208. Of course, these criteria harken back to traditional just war theory. See Brunnée and Toope, 'Slouching Towards New 'Just Wars'”.

${ }^{26}$ In Larger Freedom, paras. 122 and 125.

${ }^{27}$ Ibid., para 126.

${ }^{28}$ Ibid.

${ }^{29}$ UN General Assembly, Summit Outcome, para.138. 'Ethnic cleansing' is not established as a distinct international crime, but it is included in the concepts of 'genocide,' 'extermination,' 'deportation or forcible transfer of population' and 'enforced disappearance' as set out inter alia in Arts. 6 and 7 of the Rome Statute of the International Criminal Court, UN Doc. A/CONF.183/9 (17 July 1998). Depending upon factual circumstances, it might also be a 'war crime.'

${ }^{30}$ Summit Outcome, paras. 138 and 139.
} 
international crimes. ${ }^{31}$ The member states did not take up the earlier recommendations to develop more specific criteria for military intervention. The document contains only a charge to the General Assembly to 'continue consideration of the responsibility to protect...and its implications, bearing in mind the principles of the Charter and international law. ${ }^{, 32}$

The story we have traced so far is one of concerted norm entrepreneurship by a variety of actors. The norm was articulated and progressively refined in expert reports and in a detailed response by Secretary General Annan. Various non-governmental organizations have also been active in promoting the norm. ${ }^{33}$ Through the negotiations of the Summit Outcome, the norm was brought into the inter-state arena, where it was cast into terms that resonated more explicitly with existing international law. And, as we are about to detail, the Security Council, the Secretary General, Ban Ki-Moon, and the General Assembly have since all shown support for the responsibility to protect as articulated in the Summit Outcome.

The UN Security Council, in 2006, adopted a resolution that endorsed the concept as expressed in the Summit Outcome, ${ }^{34}$ and another invoking it with respect to the situation in Darfur. ${ }^{35}$ In January 2009, the Secretary-General released a major report on 'Implementing the responsibility to protect.' The report elaborates on the 'three pillar' approach (primary responsibility of each state; international responsibility to build capacity to that end; and collective responsibility to act if national authorities are manifestly failing to protect) that underlies the Summit Outcome's articulation of the responsibility to protect. ${ }^{36}$ The report stresses the strict focus of the concept on genocide, war crimes, ethnic cleansing, and crimes against humanity, which firmly anchors the responsibility to protect in existing international law. ${ }^{37}$ It also emphasizes that the responsibility to protect, as endorsed by the General Assembly in 2005, 'is an ally of sovereignty, not an adversary' and 'seeks to strengthen sovereignty, not weaken it. ${ }^{, 38}$ Hence we see a strong emphasis on the primary responsibility of each state and the international responsibility to support states in their efforts to protect their populations. ${ }^{39}$ As well we have a conceptualization of 'sovereignty as responsibility' and an effort to

\footnotetext{
${ }^{31}$ Ibid., para 139.

${ }^{32}$ Ibid., para 139.

${ }^{33}$ See e.g. the recently launched (28 January 2009) Responsibility to Protect-Engaging Civil Society, at www.responsibilitytoprotect.org; the Global Centre for the Responsibility to Protect, at www.globalcentrer2p.org; the R2P Coalition, at www.r2pcoalition.org; and the Asia-Pacific Centre for the Responsibility to Protect, at www.r2pasiapacific.org.

${ }^{34}$ See United Nations Security Council Resolution 1674, 28 April 2006, UN Doc. S/RES/1674, para. 4 (reaffirming paras. 138 and 139 of the 2005 Outcome); at www.un.org/Docs/sc/unsc_resolutions06.htm.

${ }^{35}$ United Nations Security Council Resolution 1706, 31 August 2006, UN Doc. S/RES/1706, preamble (recalling Resolution 1674, as well paras. 138 and 139 of the 2005 Outcome); at www.un.org/Docs/sc/unsc_resolutions06.htm.

${ }^{36}$ Implementing the responsibility to Protect, paras. 11 \& 12, and 13-66.

${ }^{37}$ Ibid., paras. 2 \& 3, and 10 (b).

${ }^{38}$ Ibid., para. 10 (a).

${ }^{39}$ Ibid., paras. 13-48.
} 
distance the responsibility to protect from the controversial notion of a 'right' to humanitarian intervention. ${ }^{40}$

Yet, the Secretary General's report is also clear that 'sovereignty does not bestow impunity' and that there is an international responsibility to 'respond collectively in a timely and decisive manner' when a state is manifestly failing in its protective responsibility. ${ }^{41}$ Collective enforcement measures could include targeted sanctions imposed by the Security Council, or indicated by the General Assembly under the 'uniting for peace' procedure. ${ }^{42}$ However, as the report underscores, 'the responsibility to protect does not alter, indeed it reinforces, the legal obligations of Member States to refrain from the use of force except in conformity with the Charter. ${ }^{, 43}$ Coercive military action is reserved for 'extreme cases' and must be authorized by the Security Council 'or by regional or subregional arrangements under Article 53 [of the Charter], with the prior authorization of the Security Council. ${ }^{44}$

The report offers two further observations in relation to possible military action, both of which pick up on recommendations in some of the earlier reports. First, the Secretary General's report urges the five permanent members of the Security Council to 'reach a mutual understanding' to refrain from employing or threatening the use of their veto power 'in situations of manifest failure to meet obligations relating to the responsibility to protect, as defined in paragraph 139 of the Summit Outcome. ${ }^{45}$ And, second, the report asks UN members to 'consider the principles, rules and doctrine that should guide the application of coercive force,' pointing out that 'the credibility, authority and hence effectiveness of the United Nations in advancing the principles relating to the responsibility to protect depend, in large part, on the consistency with which they are applied. ${ }^{46}$

The Secretary General's report was presented to the UN General Assembly in July 2009. A formal plenary debate ensued, during which speakers representing all parts of the world took the floor to offer the views of member states and various groupings of states. Taken together, these interventions suggest gathering support for the responsibility to protect, especially when compared to the debates leading up to the 2005 Summit. During these earlier debates, strong support for the concept came largely from Northern countries, such as the members of the EU, Australia, Canada, Iceland, Japan, New Zealand and Norway. Several states, including some Arab states, Cuba, Iran, Pakistan, Venezuela, and Vietnam, rejected the responsibility to protect as an unacceptable intrusion into state sovereignty. Others, including Malawi speaking on behalf of the Group of African States, were more open to the idea, but were concerned that collective security might come to be defined in terms of the responsibility to protect and serve as a

\footnotetext{
${ }^{40}$ Ibid., paras. $7 \& 10$ (a).

${ }^{41}$ Ibid., paras. 11 (c), 54.

${ }^{42}$ Ibid., paras. 56-57, 63.

${ }^{43}$ Ibid., para.3.

${ }^{44}$ Ibid., para. 56 .

${ }^{45}$ Ibid., para. 61.

${ }^{46}$ Ibid., para. 62.
} 
pretext for intervention. Yet others, such as Colombia, Indonesia, Mexico, were noncommittal and called for more discussion. Some, such as Bulgaria, Chile, Russia, Tanzania, insisted on the role of the Security Council. ${ }^{47}$ The Non-Aligned Movement (NAM) of states expressed 'its rejection of the so-called "right" of humanitarian intervention, which has no basis either in the UN Charter or in international law,' observed 'the similarities between the new expression 'responsibility to protect' and 'humanitarian intervention',' and wished 'to carefully study and consider further the expression 'responsibility to protect' and its implications on the basis of the principles of non-interference and non-intervention as well as the respect for territorial integrity and national sovereignty of States. ${ }^{48}$

The 2009 plenary debate appeared to get off to a rocky start, with the President of the General Assembly, Miguel d'Escoto Brockmann of Nicaragua, prefacing the session in a 'concept note' that questioned the international community's responsibility to protect. The note echoed many of the above-mentioned criticisms of the concept, warning that '[c]olonialism and interventionism used responsibility to protect arguments,' emphasizing that the responsibility to protect is solely 'a sovereign's obligation,' and arguing that the use of force provisions of the Charter would not 'cover responsibility to protect unless the situation is a threat to international peace and security. 49 The concerns expressed by the President, especially relating to the use of force, were taken up by some participants in the plenary debate. A large majority of member states, however, were supportive of the responsibility to protect as articulated in the 2005 Summit Outcome, which, according to China, had provided a 'prudent description' of the concept. ${ }^{50}$ Several areas of convergence and points of concern are worth highlighting for present purposes.

Almost sixty member states echoed the Secretary General's view that the responsibility to protect was anchored in existing international law. ${ }^{51}$ For example, Sweden, speaking on behalf of the European Union and several other states, expressed its support for the Secretary General's report, and indicated that the obligations inherent in 'responsible sovereignty' were 'firmly embedded in international law. ${ }^{\text {, } 2 ~ R u s s i a ~ n o t e d ~ t h a t ~ t h e ~}$

\footnotetext{
${ }^{47}$ See Review of the Secretary-General's Report "In larger freedom: towards development, security and human rights for all”, 6-8 April 2005, Verbatim Records A/59/PV.85 | A/59/PV.86 | A/59/PV.87 |

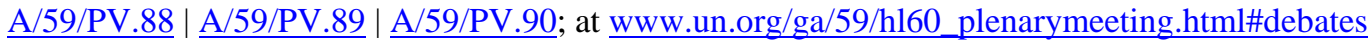

${ }^{48}$ Comments of the Non-Aligned Movement on the Observations and Recommendations Contained in the Report of the High-level Panel on Threats, Challenges and Change, 28 February 2005, paras. 14-15; at www.un.int/malaysia/NAM/Positionpaper280205.doc.

${ }^{49}$ Office of the President of the General Assembly, Concept note on responsibility to protect populations from genocide, war crimes, ethnic cleansing and crimes against humanity, 17 July 2009; at http://responsibilitytoprotect.org/R2P\%20programme\%20\%20concept\%20note\%20(3).pdf.

${ }^{50}$ See 'More than 40 Delegates Express Strong Scepticism, Full Support as General Assembly Continues Debate on Responsibility to Protect,' UN GA/10849, 24 July 2009; at http://www0.un.org/News/Press/docs/2009/ga10849.doc.htm.

${ }^{51}$ See Global Centre for the Responsibility to Protect, Implementing the Responsibility to Protect, p. 5.

${ }^{52}$ See Statement on behalf of the European Union by H.E. Mr. Anders Lidén, Ambassador and Permanent Representative of Sweden to the United Nations, General Assembly Debate on the Responsibility to Protect, 23 July 2009; at http://www.responsibilitytoprotect.org/EU_Sweden_ENG.pdf.
} 
language of Summit Outcome was 'in line with the Charter,' while Sri Lanka indicated that 'paragraphs 138 and 139 of the 2005 World Summit Outcome were based on preexisting norms.' ${ }^{53}$ Jamaica, speaking for the members of the Caribbean Community (CARICOM), indicated that, notwithstanding the need to achieve consensus on the responsibility to protect, 'existing international law bestows on all of us the responsibility to prevent the crime of genocide, war crimes, ethnic cleansing and other mass atrocities. $^{54}$

Many states, including the members of the European Union, Benin, Costa Rica, Lesotho, Qatar, and Timor-Leste, also agreed that mass atrocities within states could constitute threats to international peace and security, such as to enable the Security Council to take collective action. ${ }^{55}$ The United States noted, in very general terms, that collective action would '[o]nly rarely, and in extremis, ... include the use of force. ${ }^{56}$ In any case, as with all operational aspects of the responsibility to protect, including action through the Security Council, responsibility could arise only in relation to the international crimes identified in the Summit Outcome. ${ }^{57}$

Not surprisingly, the role of the Security Council and questions concerning recourse to military measures were nonetheless among the most controversial topics of debate. Cuba, Iran, North Korea, Pakistan, Sudan, and Venezuela echoed earlier NAM statements connecting the responsibility to protect to the controversial notion of humanitarian intervention, and warned against the risks of abuse of the concept to justify illegal interventions in states. ${ }^{58}$ And while a majority of states emphasized the difference between the collective security-based third pillar of the responsibility to protect and (unilateral) humanitarian interventions, several of the states that were supportive of the third pillar also raised concerns about the parameters of collective action. For example, Switzerland queried who would decide whether a situation involved one of the triggering crimes, ${ }^{59}$ while the CARICOM statement sought clarification of the circumstances in which the Security Council could resort to Chapter VII measures. ${ }^{60}$ Several states endorsed the Secretary General's proposal that consideration be given to guidelines on the use of force. For example, the Philippines considered it imperative that policies, principles and rules be laid out in cases where coercive force is applied in extreme

\footnotetext{
${ }^{53}$ See 'Delegates Weigh Legal Merits of Responsibility to Protect Concept as General Assembly Concludes Debate - Speakers Question its Effectiveness in Face of Security Council Veto Power,' UN GA/10850, 28 July 2009; http://www0.un.org/News/Press/docs/2009/ga10850.doc.htm.

${ }^{54}$ See Statement of Raymond Wolfe to the UN General Assembly, 28 July 2009; at http://www.responsibilitytoprotect.org/CARICOM\%20Statement\%20on\%20R2P\%20as\%20amendedFinal.pdf.

${ }^{55}$ Global Centre for the Responsibility to Protect, Implementing the Responsibility to Protect, p. 5.

${ }^{56}$ Remarks by Ambassador Rosemary A. DiCarlo, at a General Assembly Debate on the Responsibility to Protect, in the General Assembly Hall, July 23, 2009, at http://responsibilitytoprotect.org/USA ENG-1.pdf.

${ }^{57}$ Ibid., p. 6.

${ }^{58}$ Ibid., p. 7.

${ }^{59}$ Déclaration de S.E. M. Peter Maurer, Représentant permanent de la Suisse auprès des Nations Unies - La mise en oeuvre de la responsabilité de protéger, 23 July 2009, p. 3; at http://www.responsibilitytoprotect.org/Switzerland_ENG_FR.pdf.

${ }^{60}$ See Statement of Raymond Wolfe, p. 2.
} 
situations. ${ }^{61}$ Finally, a sizeable number of member states expressed concerns about Security Council paralysis, and endorsed the Secretary General's recommendation that the veto power not be used in situations involving the responsibility to protect. ${ }^{62}$ Some statements linked progress on the responsibility to protect to calls for reforms for a more representative Security Council. ${ }^{63}$

On 14 September 2009, the General Assembly adopted a short and carefully balanced resolution on the responsibility to protect. ${ }^{64}$ In it, it reaffirmed its respect for the principles and purposes of the UN Charter, recalled paragraphs 138 and 139 of the Summit Outcome, takes note of the Secretary General's report on implementation and the 'timely and constructive' debate on the report, and decides 'to continue its consideration of the responsibility to protect.' Revealing the reservations that some states continue to have, it was only the removal of the words 'with appreciation' from the operative paragraph taking note of the Secretary General's report that enabled adoption of the resolution by consensus. ${ }^{65}$

\section{The Responsibility to Protect: A Legal Norm?}

Drawing together insights from constructivist approaches to international relations and the legal theory of Lon Fuller we have developed a novel account of how international law is made, maintained or destroyed. ${ }^{66}$ Constructivism helps us illuminate how norms emerge and shape social interaction. ${ }^{67}$ Fuller's work provides a set of criteria of legality that enables us to identify legal norms and explain their distinctive influence. ${ }^{68}$ Briefly put, our three-pronged framework posits that legal norms arise when shared normative understandings evolve to meet the criteria of legality, and become embedded in a practice of legality. Given the central importance of social and legal interaction in this framework, we refer to it as an 'interactional' account of international law. As we hope to illustrate in the following assessment of the responsibility to protect norm, our framework provides a richer understanding of the emergence and evolution of legal

\footnotetext{
${ }^{61}$ Statement of H.E. Mr. Hilario G. Davide, Jr., Ambassador Extraordinary and Plenipotentiary, Permanent Representative of the Republic of the Philippines to the United Nations in New York - Thematic Debate on the Report of the Secretary-General on Implementing The Responsibility to Protect (A/63/677), 23 July 2009, p. 4; at http://www.responsibilitytoprotect.org/Philippines_ENG.pdf.

${ }^{62}$ See Global Centre for the Responsibility to Protect, Implementing the Responsibility to Protect, p. 6-7 (counting 35 states, including Costa Rica, Denmark, Malaysia, New Zealand, Norway, Rwanda, Singapore, South Africa, and Timor-Leste).

${ }^{63}$ Ibid. (citing CARICOM, Gambia, India, and Sudan).

64 UN General Assembly Resolution 63/308, UN Doc. A/RES/63/308, 7 October 2009; at http://daccessdds.un.org/doc/UNDOC/GEN/N09/513/38/PDF/N0951338.pdf?OpenElement.

${ }^{65}$ See Global Centre for the Responsibility to Protect, Summary of Statements on Adoption of resolution RES A/63/L80 Rev. 1 - $\quad$ R September 2009; http://globalr2p.org/media/pdf/GCR2P_Summary_of_Statements_on_Adoption_of_Resolution_on_R2P.pd $\underline{\mathrm{f}}$.

${ }^{66}$ See Brunnée and Toope, Legitimacy and Legality in International Law.

${ }^{67}$ See Ian Hurd, 'Constructivism', in Christian Reus-Smit and Duncan Snidal, eds., The Oxford Handbook of International Relations (Oxford: Oxford University Press).

${ }^{68}$ See Lon L. Fuller, The Morality of Law, Rev. ed. (New Haven: Yale University Press, 1969).
} 
norms than an analysis that uses the customary or treaty status of a norm as the sole indicator of legality.

\section{Shared Understandings}

Social norms can only emerge when they are rooted in an underlying set of shared understandings supporting first the need for normativity, and then any particular norms that shape behavior. ${ }^{69}$ Shared understandings are collectively held background knowledge, including social norms and practices. But these understandings do not simply exist, or spontaneously emerge as agreed among actors. They are shared understandings precisely because they are intersubjective - generated and maintained through social interaction. On the one hand, actors generate and promote particular understandings, whether through norm entrepreneurship or through the work of epistemic communities. Shared understandings then emerge, evolve or fade through processes of social learning. ${ }^{70}$ On the other hand, once in existence, shared understandings shape how actors perceive themselves and the world, how they form interests and set priorities, and how they make arguments or evaluate others' arguments. ${ }^{71}$

It is noteworthy that the norm building process surrounding the responsibility to protect has been sensitive to the need for widely shared understandings, and to the fact that such understandings must be cultivated over time. ${ }^{72}$ Textual representations of a norm can be helpful in this process, but they cannot themselves be taken as reflective of a social norm. It is important, therefore, that the Summit Outcome has not been treated as the culmination of the norm building process, but rather as a platform for further normative interaction and deliberation. The Secretary General's report on the implementation of the responsibility to protect clearly reflects the recognition of the need for wider and deeper support for the norm that was delineated in the Summit Outcome, as well as for further elaboration and clarification of its meaning. The 2009 General Assembly debate on the Secretary's report provides a window on states' views and so allows, with all due caution, an assessment of the currently shared normative ground. The almost universal participation in the debate, either directly or through endorsement of group statements, is particularly significant in this context.

A full review of the interventions in the debate is beyond the scope of this article. But it is safe to conclude that the understanding of the responsibility to protect that is outlined in paragraphs 138 and 139 of the Summit Outcome is shared by a growing number of

\footnotetext{
${ }^{69}$ Brunnée and Toope, Legitimacy and Legality in International Law., Ch. 2.

${ }^{70}$ Alexander Wendt, Social Theory of International Politics (Cambridge University Press, 1999); Etienne Wenger, Communities of Practice: Learning, Meaning, and Identity (Cambridge University Press, 1998).

${ }^{71}$ Emanuel Adler and Steven Bernstein, 'Knowledge in Power: The Epistemic Construction of Global Governance', in Michael Barnett and Raymond Duvall, eds., Power in Global Governance (Cambridge University Press, 2005).

${ }^{72}$ For a detailed discussion, see Ramesh Thakur and Thomas G. Weiss, 'R2P: From Idea to Norm, and Action?' Global Responsibility to Protect 1: 22-53 (2009).
} 
states from all parts of the world. ${ }^{73}$ As we noted earlier in this article, the members of the African Union had endorsed the responsibility to protect at a regional level long before its inclusion in the Summit Outcome. In the lead-up to the 2005 Summit, they reaffirmed their commitment to the principle in a common position on UN reform. ${ }^{74}$ More generally speaking, while concerns about abuses of the concept linger, the number of states that are categorically opposed to its collective action aspects, including use of force through the Security Council as a last resort, appears to be shrinking. ${ }^{75}$ It is also noteworthy that the NAM statement offered on the occasion of the debate was considerably softer than the earlier statements of the movement. The statement merely notes 'mixed feelings' about the implementation of the responsibility to protect, and 'concerns' about its possible abuse beyond the four crimes listed in the Summit Outcome, 'to legitimize unilateral coercive measures or intervention in the internal affairs of States. ${ }^{76}$ Furthermore, it has been noted that many of the 118 NAM member states 'appeared to break with tradition by not explicitly aligning themselves with the NAM statement.' 77

The emphasis of the continuing debate appears not to be on challenging the concept of the responsibility to protect as such, but on refining it, especially as it relates to the use of force. Indeed, seen through the lens of our conceptual framework, the proposals in the Secretary General's report, as well as many of the interventions in the General Assembly debate, seem at least in part designed to strengthen the legality of the norm.

\section{The Criteria of Legality}

Legal norms are rooted in shared social understandings. Such understandings may be largely procedural in nature, such as rules that govern international institutions or decision-making processes, or they may be more substantive and value-laden, as in the case of the emerging responsibility to protect norm. However, shared understandings alone do not make law. ${ }^{78}$ Many social norms exist that never reach the threshold of legal normativity. We have already suggested that this threshold is marked by adherence to specific criteria of legality. Lon Fuller set out eight such criteria, which apply to both individual rules and systems of rule-making. Legal norms must be general, prohibiting,

\footnotetext{
${ }^{73}$ Global Centre for the Responsibility to Protect, Summary of Statements, pp. 10-11 (detailing the patterns of support in Africa, Asia and Pacific, Latin America and the Caribbean, the Middle East, and Eastern and Western Europe).

${ }^{74}$ See African Union (AU), The Common African Position on the Proposed Reform of the United Nations: The Ezulwini Consensus, March 7-8, 2005, AU Doc. Ext/EX.CL/2 (VIII).

${ }^{75}$ Cuba, Nicaragua, Pakistan, Sudan, the People's Republic of Korea, and Venezuela are the most vocal of these states. See International Coalition for the Responsibility to Protect, Report on the General Assembly Debate on the Responsibility to Protect., 15 September 2009, pp. 7-8; at http://responsibilitytoprotect.org/ICRtoPGAdebate.pdf.

${ }^{76}$ See Statement by Egypt on behalf of the Non-Aligned Movement, Agenda Item 44 and 107: "Integrated and coordinated implementation of and follow-up to the outcomes of the major United Nations conferences and summits in the economic, social and related fields; Follow-up to the outcome of the Millennium Summit: report of the Secretary- General,” p. 1; at http://www.responsibilitytoprotect.org/NAM_Egypt_ENG.pdf.

${ }^{77}$ See Global Centre for the Responsibility to Protect, Implementing the Responsibility to Protect, p. 4.

${ }^{78}$ Brunnée and Toope, Legitimacy and Legality in International Law, Ch. 3.
} 
requiring or permitting certain conduct. They must also be promulgated, and therefore accessible to the public, enabling actors to know what the law requires. Law should not be retroactive, but prospective, enabling actors to take the law into account in their decision-making. Actors must also be able to understand what is permitted, prohibited or required by law - the law must be clear. Law should avoid contradiction, not requiring or permitting and prohibiting at the same time. Law must be realistic and not demand the impossible. Its requirements of actors must remain relatively constant. Finally, there should be congruence between legal norms and the actions of officials operating under the law. ${ }^{79}$

The responsibility to protect norm as articulated in the Summit Outcome addresses some of these legality requirements, but falls short on others. The inclusion of the responsibility to protect in the Outcome serves some aspects of the promulgation requirement. While it did not promulgate the norm into law, it did publicize the foundations upon which a legal norm would grow and set the parameters for further normative debate. In turn, the fact that the Outcome tied the responsibility to protect to a set of established international crimes speaks to a number of the legality requirements. Compared to the formulations of triggering events in the ICISS and High Level Panel reports, the Outcome's linking of the responsibility to existing legal categories significantly enhances the clarity of the triggering events and scope of the norm. ${ }^{80}$

The linkage also ensures the norm's consistency with established international law - a point that was stressed in the Secretary General's report and by several participants in the Assembly debate - thereby addressing the requirements of non-contradiction and constancy over time. Indeed, individual states' responsibilities to protect their own populations from the listed crimes as well as the international responsibilities to assist and, if necessary, to take collective action through the Security Council, are grounded inter alia in the law of state responsibility. ${ }^{81}$ In limiting the responsibility to protect to 'genocide, war crimes, ethnic cleansing and crimes against humanity,' the Outcome tied the responsibility to protect to norms that are widely considered to have both erga omnes effect and jus cogens status. ${ }^{82}$

If this assessment is correct, much of the responsibility to protect is a specific articulation of the general consequences that international law attaches to the violation of jus cogens

\footnotetext{
${ }^{79}$ Colleen Murphy, 'Lon Fuller and the Moral Value of the Rule of Law' Law and Philosophy 24: 239, at 240-241 (2005).

${ }^{80}$ But see Carlo Focarelli, 'The Responsibility to Protect Doctrine and Humanitarian Intervention: Too Many Ambiguities for a Working Doctrine,' J. Confl. \& Sec. L. 13: 191-213 (2008).

${ }^{81}$ See International Law Commission (ILC), Draft Articles on Responsibility of States for Internationally Wrongful Acts, in Report of the International Law Commission on the Work of Its Fifty-third Session, UN GAOR, 56 ${ }^{\text {th }}$ Sess., Supp.No. 10, 43, UN Doc. A/56/10 (2001).

${ }^{82}$ See also Ekkehard Strauss, 'A Bird in the Hand is Worth Two in the Bush - On the Assumed Legal Nature of the Responsibility to Protect' Global Responsibility to Protect 1: 291-323 (2009). (As noted above, however, 'ethnic cleansing' is not a separate international crime, but falls within a number of established categories.)
} 
and erga omnes norms. ${ }^{83}$ Notably, by virtue of their erga omnes effect, states already owe the human rights obligations underlying the responsibility to protect not only to persons under their jurisdiction, but also to all states. By the same token, all states already have a legal interest in the protection of individual states' populations against these grave human rights abuses. In the face of such abuses, all states could invoke the responsibility of the perpetrating state, and could demand that the abuses stop. If the state perpetrating the abuses refuses to comply, all states are further entitled to take 'lawful measures' to compel compliance. ${ }^{84}$

General international law underscores that third states' concerns over extreme human rights abuses within an individual state are not unwarranted interventions in internal affairs, but the legitimate pursuit of collective legal interests. But what of the greatest innovation of the responsibility to protect, the idea that third states not only have legal interests but also legal responsibilities? A closer look reveals that here too the responsibility to protect against 'genocide, war crimes, ethnic cleansing and crimes against humanity' rests on the foundations of the law of state responsibility. In the case of jus cogens violations, the law of state responsibility instructs that states are not merely entitled to demand that they stop but are under an obligation to cooperate to bring them to an end. ${ }^{85}$ Again, therefore, the responsibility to protect concept makes explicit what international law already requires.

The Outcome also tracks the current state of the law on the use of force. It does not seek to introduce any new 'right' - or responsibility - of military intervention for individual states. Rather, it keeps recourse to force firmly in the hands of the Security Council. The document leaves open, however, whether collective action 'in accordance the Charter, including Chapter VII' presupposes that a situation involving the listed crimes must first be found to constitute a threat to international peace and security, whether all such situations would constitute threats to peace and security, or whether the Security Council can intervene whenever a state is 'manifestly failing' to protect their populations. If the determination of a threat to peace and security does remain a threshold requirement, then the responsibility to protect will be tied to a deliberately fluid and broadly political decision-making criteria. It also remains unclear to what extent the Security Council has an obligation to intervene if necessary to protect populations from the listed crimes, ${ }^{86} \mathrm{a}$ proposition roundly rejected by some key states. ${ }^{87}$ The Summit Outcome's reference to 'case-by-case' decisions on the use of force would seem to suggest there is no such obligation. Rather, it maintains space for political assessments and tends to weaken the

\footnotetext{
${ }^{83}$ See generally Christian Tams, Enforcing Obligations Erga Omnes in International Law (Cambridge: Cambridge University Press, 2005); and see Ian Scobbie, 'The Invocation of Responsibility for the Breach of 'Obligations under Peremptory Norms of General International Law',' EJIL 13: 1202 (2002).

${ }^{84}$ ILC, Draft Articles on Responsibility, Articles 48 \& 54.

${ }^{85}$ Ibid., Article 41.

${ }^{86}$ See Stephen J. Toope, 'Does International Law Impose a Duty upon the United Nations to Prevent Genocide?' McGill Law Journal 46: 187 (2000); and see Louise Arbour, 'The Responsibility to Protect as a Duty of Care in International Law and Practice’ Review of International Studies 34: 445 (2008).

${ }^{87}$ Notably, the United States took this position during the April 2005 General Assembly debates on Secretary General's In Larger Freedom report. See U.N. Doc. A/59/PV.87, p. 23.
} 
legality of the responsibility to protect as regards the requirements of generality, clarity and constancy over time. Concerns regarding the generality of the norm are also heightened by the limited membership of the Security Council, and the role of the five permanent members in its decision-making, notably through their veto.

In light of these weaknesses of the responsibility to protect as articulated in the Summit Outcome, it is of interest that many of the interventions in the 2009 General Assembly debate raise legality concerns, especially about the use of force element of the responsibility to protect. Furthermore, the main proposals for further development of the principle would all serve to strengthen the legality of the norm. For example, the calls for a more representative Security Council speak to the concern about generality. The Swiss question who would decide whether a crisis situation involved a triggering crime speaks to the clarity requirement, as well as to the delineation between legal and political space. The same is true for CARICOM's request for clarification on the circumstances in which the Security Council could resort to collective action. In turn, the strong emphasis, in the Secretary General's Report and in several states' plenary statements, on the need for guidelines on the use of force underscores the importance of generality, clarity and constancy. Guidelines, such as those proposed by ICISS or the High Level Panel, would significantly enhance the legality of the norm by subjecting case-by-case decisions to over-arching criteria that identify the extreme and exceptional cases to which military intervention should be restricted. They would also highlight cases in which force should in fact be used, and demand a reasoned justification of inaction. Finally, the call for nonuse of the veto in cases involving one of the listed crimes is also related to legality considerations. The veto power for the five permanent members undercuts the generality of protective force option, and weakens the potential for consistent decision-making by the Council.

\section{The Practice of Legality}

We have not yet addressed the last criterion of legality, the requirement that official action be congruent with existing law. So as to avoid repetition, we will blend our consideration of congruence, as a criterion of legality, into our investigation of the last step in determining the legal force of the responsibility to protect, deciding whether or not the practice of legality supports the existence of a legal norm. If there is no congruence between norm and action, no practice of legality, we will have to conclude that the responsibility to protect has not yet emerged as a legal norm.

Fuller, whose work was preoccupied with national legal systems, emphasized the need for 'reciprocity' between officials and citizens in the creation and sustenance of all law. ${ }^{88}$ He illustrated that what is often assumed to be a vertical relationship (of authority and subordination) actually has strong horizontal features, ${ }^{89}$ a proposition that makes his work particularly relevant to international law. Reciprocity, in Fuller's conception, means that law-givers must be able to expect that citizens will "accept as law and

\footnotetext{
${ }^{88}$ Fuller 1969a.

${ }^{89}$ Fuller 1969a.
} 
generally observe" the promulgated body of rules. ${ }^{90}$ However, in order for these rules to be able to guide their actions, they must meet the requirements of legality. Therefore, conversely, citizens must be able to expect that the government will abide by and apply these rules, that the actions of officials will be congruent with posited law, and consonant with the requirements of legality. ${ }^{91}$

The reciprocity that underpins law, then, is deeper than the exchange flowing from the calculation of material interests. When the eight criteria of legality are met, actors will be able to reason with rules because they will share meaningful standards. In international society, the deeper sense of reciprocity that we just described is even more relevant because states are both subjects and lawmakers. To the extent that international law is created without congruence with shared norms and the criteria of legality, neither commitment to law nor a sense of obligation amongst states will be generated. The central insight is that, in international law, the kind of reciprocity that we are speaking of is created and maintained collectively. To be sure, not all members of international society must be engaged in this enterprise. International law can withstand individual defiance so long as a solid majority of actors works to uphold legality. But when explicit rules are unrelated to how states and other international actors actually behave, commitment to law cannot arise or is eventually destroyed.

The fact that reciprocity requires collective effort also serves to underscore why claims to legal 'exceptionalism' by powerful states can be so corrosive. Some states will be actively resentful when confronted with such claims, or with other failures to meet the requirements of legality. This dynamic was well illustrated by the strong reactions to US assertions of a right to preventive self-defence that went beyond the generally accepted bounds of the right to self-defence. ${ }^{92}$ The same is true for the 2003 intervention in Iraq by a US and UK-led 'coalition of the willing,' which was tenuously justified on the basis of purported Security Council authorization. ${ }^{93}$ The NATO intervention in Kosovo also raised concerns among many states about some states arrogating to themselves a right to intervene outside of the existing rules on the use of force. ${ }^{94}$ These examples, all of which strain the legality requirements imposed by the existing rules on the use of force, form part of the experience that has led many developing countries to be suspicious of the third pillar of the responsibility to protect.

\footnotetext{
${ }^{90}$ Fuller 1969b, 235.

${ }^{91}$ Fuller 1969a.

${ }^{92}$ See Jutta Brunnée and Stephen J. Toope, 'The Use of Force: International Law After Iraq' (2004) 53 International \& Comparative Law Quarterly 785. What is more, since the right was tied to unilateral assessment of emerging threats, it ultimately did not contain a rule that could be generally applied. See also Richard B. Miller, 'Justifications of the Iraq War Examined' Ethics \& International Affairs 22: 43 (2008), pp. 52-53 (noting that "[p]reventive war doctrine is not generalizable to situations of parity between states”).

${ }^{93}$ See United Nations Security Council Press Release SC 7705, 'Security Council Holds First Debate on Iraq since Start of Military Action; Speakers Call for Halt to Aggression, Immediate Withdrawal', 26 March 2003, at www.un.org/News/Press/docs/2003/sc7705.doc.htm.

${ }^{94}$ See Jules Lobel and Michael Ratner, 'Bypassing the Security Council: Ambiguous Authorizations to Use Force, Cease-Fires and the Iraqi Inspection Regime’ American Journal of International Law 93: 124 (1999) pp. 130-134.
} 
The considerations inherent in the congruence requirement have obvious salience for the responsibility to protect and the use of protective force through the Security Council. As we have seen, the norm as it currently stands fails on some of the traits of legality that would enhance its ability to guide decision-making. But it also falls short on the congruence requirement. International practice so far has not invoked the responsibility to protect to justify collective recourse to force. Past practice under the banner of protective force (or 'humanitarian intervention') has been notoriously uneven. Hence, many states and other observers do not expect the Security Council to apply the responsibility to protect norm with any consistency. Rather, the expectation is that a body in which powerful states hold veto rights will always produce politically and strategically motivated action and inaction. Indeed, the congruence requirement instructs that it would not be enough to adopt a General Assembly or Security Council resolution that concretizes the collective responsibility to protect through guidelines on the use of force or an undertaking by the permanent members not to exercise their veto. Even if the norm's legality were to be further developed along these lines, the responsibility to protect will not emerge as a global legal norm unless there also emerges a practice that consistently upholds the norm and adheres to the requirements of legality. ${ }^{95}$

\section{Conclusion}

The responsibility to protect, including its potential for collective action, is increasingly supported by globally shared understandings. However, the norm falls short on several of the legality criteria that we highlighted in this article, notably on generality, clarity, consistency, and constancy over time. Furthermore, given the inconsistent practice on protective use of force, no practice of legality can be said to have evolved. Nonetheless, the current discourse confirms that the Summit Outcome provided an accurate snapshot of the emerging norm, and a well-crafted platform for efforts to build up its legality. Continuing debates over the parameters for collective action reveal concerted efforts to strengthen the legality of the emerging norm.

If these efforts to promote a legal responsibility to protect were to succeed, decisionmaking in the Security Council would be significantly affected. Resistance to the further evolution of a legal responsibility to protect is not, therefore, likely to be limited to members of the NAM who fear the erosion of a hard-won sovereignty. The evolution of the responsibility to protect into a legal norm would shrink the space for political assessments in cases involving failures to protect populations against grave crimes, likely prompting some of the veto-holding powers to demur from a hard norm as well. Security Council decisions would have to meet the requirements of the responsibility to protect, and would be measured against the criteria of legality. For better or for worse, efforts to

\footnotetext{
${ }^{95}$ The same applies at a regional level. Observers have noted, for example, that the AU's practice in relation to the responsibility to protect enshrined in its Constitutive Act 'does not reflect a clear commitment' to the norm. See Kwesi Aning and Samuel Atuobi, 'Responsibility to Protect in Africa: An analysis of the African Union's Peace and Security Architecture,' Global Responsibility to Protect 1: 90113 (2009), p. 113.
} 
promote the emergence of a collective legal responsibility to protect raise sensitive questions about the role of law and politics in Security Council decision-making. Proponents of the norm face a lot of hard work ahead. 